\title{
Comparative study of the effect of face-to- face and computer mediated conversation modalities on student engagement: speaking skill in focus
}

\author{
Maryam Bagheri and Zohre Mohamadi Zenouzagh ${ }^{*}$ (1)
}

\author{
* Correspondence: Zohre. \\ mohamadi@kiau.ac.ir \\ Dr. Zohre Mohamadi is an associate \\ professor at English translation \\ department of Islamic Azad \\ University, Karaj branch, Karaj, Iran. \\ She has published in the areas of \\ discourse, interaction, and \\ conversation analysis, teaching \\ English as a foreign language and \\ computer assisted language \\ learning. She has published several \\ articles on writing skill and \\ computer assisted language \\ learning. Currently she is working \\ on teacher education and \\ development. \\ English Translation and Teaching \\ Department, Karaj Branch, Islamic \\ Azad Univeristy, Karaj, Iran
}

\begin{abstract}
This study investigated the potentials of face -to- face and computer mediated conversation (CMC) as two speaking modalities on students' engagement. To this end, 30 Iranian male intermediate EFL learners were selected on the basis of their performance on OPT (Oxford Placement Test) and assigned into the research groups. The progression of face- to- face and CMC groups from limited to elaborate engagement at verbal, paralinguistic and functional levels was assessed using transcription analysis in face-to-face group and chat log analysis in CMC group. The limited and elaborate student engagement indicators in two modalities were identified via Maxqda software. The results of Maxqda analysis indicated that limited engagement was associated with appeal for help, silence, pauses and hesitations, focus on syntax, involvement with procedural talk and L1 use. Respectively, elaborate engagement was associated with avoiding L1 use, focus on discourse, involvement with actual talk and strategic discourse management rather than pause and silence. Chi-square analysis on frequency of indicators of limited and elaborate engagements on verbal, paralinguistic and functional levels indicated that limited and elaborate engagements occurred with different proportions in face-to-face and CMC conversations. Teaching practitioners would benefit the findings of the study since the findings illustrate how students' engagement in learning evolves and how speaking modalities may impact the pattern of students' engagement over time. The finding also suggest one way for improving student engagement without over-intervening of teachers is using modalities such as forums where the teacher presence is limited and students have to manage the discourse themselves which in turn increases student engagement.
\end{abstract}

Keywords: Student engagement, Speaking modalities, Face-to-face conversation, Computer mediated conversation

\section{Introduction}

Speaking is the main language skill; however, majority of students and learners in EFL contexts struggle to overcome their speaking difficulties since their exposure to situations where speaking skill could be practiced is scarce (Agudo, 2019; Ding, Er, \& Orey, 2018). Through the golden age of technology, speaking English fluently has been

(c) The Author(s). 2021 Open Access This article is licensed under a Creative Commons Attribution 4.0 International License, which permits use, sharing, adaptation, distribution and reproduction in any medium or format, as long as you give appropriate credit to the original author(s) and the source, provide a link to the Creative Commons licence, and indicate if changes were made. The images or other third party material in this article are included in the article's Creative Commons licence, unless indicated otherwise in a credit line to the material. If material is not included in the article's Creative Commons licence and your intended use is not permitted by statutory regulation or exceeds the permitted use, you will need to obtain permission directly from the copyright holder. To view a copy of this licence, visit http://creativecommons.org/licenses/by/4.0/. 
considered a must specifically for people who want to progress in certain fields of human endeavour. Eligibly in the current globalized world, differences in technical and technological development are quickly fading. However, the methodology of designing and conducting the computer mediated process of instruction is still missing (Lin, 2020; Mohamadi, 2018b). Generally, social networks were primarily exploited for communication with family and friends, sharing photos and materials of interest. This support to social networks from the public should be exploited for educational purposes and learners' motivation. In practice, despite their disadvantages (small screen) to present the (learning) content and thanks their advantages (low weight, small size), CMC (computer mediated communication devices have become the most frequently used means of access to social networks (Jiang \& Zhang, 2020).

Having recognized the potential of technology-mediated learning for supporting students' learning, we examined how it may influence students' learning effectiveness and satisfaction, using face-to-face learning as a comparative baseline. Consistent with the analysis provided by Clark (1994), we posit that a learning medium by itself cannot determine students' learning effectiveness or satisfaction. Rather, the differential outcomes in technology-mediated versus face-to-face learning resulted from students' learning engagement can affect their learning effectiveness and satisfaction in technology-mediated learning (Piccoli, Ahmad, \& Ives, 2001). Therefore, modality which is the medium or channel through which communication intent is expressed and information is encoded plays a significant role (Pereira, 2010). Digital environments in language learning are computer-mediated communications (CMC) such as email, text messaging, instant messaging, blogs and journaling, Skype, Facebook. CMC relates to the use of these online resources; either in text or audio basis, to compose and exchange information through social networking system (Bataineh \& Hani, 2011). These technologies have created interactive environments for language learning and have raised essential questions concerning whether networked technology facilitates interaction and influences learning processes (Batianeh, 2014; Mohammadi, 2017).

The conceptual analysis is also built on by Natriello (1984) and he defines learning engagement as a student's voluntary participation in activities designed as part of the learning program. As defined here, learning engagement thus reveals students' willingness to take part in the (designed) learning activities to better acquire focal knowledge or skills. Learning engagement underscores the importance of behavioural engagement in learning (e.g., participation) and often has a positive association with emotional engagement, as signified by learning interest or satisfaction (Fredricks, Blumenfeld, \& Paris, 2004; Mohamadi, 2017).

In the field of educational psychology, the concept of student engagement has been a topic of intensive study over the past decade (Galikyan \& Admiraal, 2019); Snijders, Wijnia, Rikers, and Loyens (2020). The research on engagement covers a broad spectrum of four contexts that are hierarchical: school, community, classrooms, and learning activity (Philp \& Duchesne, 2016). Due to the varied research contexts and foci, definitions of engagement have become highly variable, with a lack of consensus in the literature (Christenson, Reschly, \& Wylie, 2012). In each context, different aspects of student engagement are highlighted as important to the particular outcomes sought at this level. For example, the original research by Finn and Voelkl (1993) on 
engagement related to the level of school and regarded students' participation or involvement as well as their sense of belonging in school.

Outcomes were measured in dropout or retention rates. In contrast, at the level of activity, student engagement is involvement in a specific activity or task in class and the outcome sought is learning. In foreign (FL) or second language (L2) settings, outcomes sought relate to language use and/or development (Ansarin \& Mohamadi, 2013a, b). We use the term task here in a specific sense. Following Ellis (2009), task refers to a particular kind of activity that involves a primary focus on meaning. Typically, tasks require the use of participants' own resources (e.g., their own language, their own ideas), and there is a clearly defined outcome (i.e., achievement of a non-linguistic goal).

Fredricks et al., (2011) and Fredricks and McColskey (2012) identified methods to measure learner engagement in K-12 contexts. These methods involve surveying students or obtaining observations from teachers about student engagement. The instruments were designed not only to capture information on students' observable behaviours, such as participation or attendance, but to identify the less observable emotional, cognitive, and social experiences as well.

So far, previous studies on the effects of online collaborative learning environments on the cognition, comprehension and learning of students (Cacciamani, Cesareni, Martini, Ferrini, \& Fujita, 2012; So, Seah, \& Toh-Heng, 2010) have focused on the knowledge building skills of students. Knowledge building is a group activity in which knowledge is intentionally developed and students collaboratively work to solve, discuss, and compare common problems and detail their ideas (Galikyan \& Admiraal, 2019; Scardamalia \& Bereiter, 2006). But few have considered the degree of student engagement discussed in terms of different levels.

One limitation to the measures examined in these reviews is that they were designed for, and in some cases can only be used in, face-to-face learning contexts. For example, a teacher report method would likely be ineffective for an online course for which teachers are not physically present to observe student behaviour. Nor do the approaches reviewed address the challenges unique to measuring student engagement in technology-mediated learning experiences. As students learn more using technology and away from traditional brick and mortar locations, measures of engagement must be appropriate to these learning contexts (Henrie, Halverson, \& Graham, 2015). The growth in access to new technologies in training offers new possibilities for L2 learners. There is now an abundance of net-based packages and materials for L2 learners to broaden their linguistic capabilities. There seems to be a growing quantity of digital technologies which allow and facilitate L2 gaining knowledge via collaborative practice and the facilitation of information and expertise sharing. Known as Computer Supported Collaborative learning (CSCL) (Lee, 2012; Lund, 2008), this area of research and improvement is seen to preserve much gaining knowledge benefits like development in educational fulfilment, and the improvement of better thinking abilities (Resta \& Laferrière, 2007). A vast array of studies in the area of CSCL has focused on conversation either synchronous or asynchronous verbal exchange (Hilliges et al., 2007) with in-class interaction gaining less interest. For ESP (English for special purposes) students verbal exchange is essential in a face to face form. On the other hand, according to Hilliges et al. (2007) classroom interaction enjoys mobile aided knowledge and language learning, which arguably keeps higher possibilities for L2 learners. 
Computer-mediated communication (CMC) systems have grown to be necessary to the initiation, development, and protection of interpersonal relationships (Cline, 2013). It includes diffused shaping of verbal exchange in almost each relational context (Cline, 2013). We might also study or take part within the conversations of large numbers of social actors, from the Twitter messages of professionals we have by no means met one's own family's weblog and from messaging a barely acquainted Facebook pal to coordinating with one's spouse via texting about who will collect the children that day. People use the capabilities of those media to make their great impact and attract interest or to beat back undesired contacts (Tong \& Walther, 2011). We always form and re-shape our impressions and reviews of others online, from deciding whose suggestions to consider in discussion forums (Walther, Van Der Heide, Kim, Westerman, \& Tong, 2008) to evaluate the buddy who portrays himself online in some proper manner (Walther, DeAndrea, Kim, \& Anthony, 2010).

The universality of CMC is not an adequate catalyst for it to be a matter of concentration in relational correspondence studies. How CMC changes our messages-how they are developed, regardless of whether for particular social purposes or with lesser or more prominent impact-stay vital inquiries that keep on driving request in relational CMC studies (Murillo-Zamorano, Sánchez, \& Godoy-Caballero, 2019; Wolverton, 2018). How does internet influence the probability of maximized learner engagement? The CMC views cooperation and engagement as a fundamental part of learning and the information building process (Ding et al., 2018; Williams, Stafford, Corliss, \& Reilly, 2018). The acknowledgment of support is troublesome without connection, and comparatively, it is normal that communication happens in a situation where there is cooperation (Glazer, Hannafin, \& Song, 2005). That is, each learner partaking in an online learning condition is really thought of as having a connection. Learner engagement in face- to face conversation in this manner is analysed against CMC conversation in the present study. The purpose of this study is to explore how student engagement differs in technology-mediated learning experiences.

\section{Literature review}

\section{Student engagement}

Beyond the definition of engagement as involvement or commitment, student engagement is also said to be multidimensional by nature (Martin \& Dowson, 2009; van der Kleij, 2020). Such multidimensional nature of student engagement has slowly shaped the concept into both a strategy for improving educational achievement and as a selfreliantly valuable outcome of education (Dunleavy \& Milton, 2009). Student engagement is regularly seen as a treatment for the contemporary students' notion of school as boring or as a mere grade game (Burkett, 2002; Pope, 2002). Student engagement is also used to describe students' willingness to join in routine school activities, such as attending class, submitting school work, and following class instructions (Chapman, 2003). Some researchers considered student engagement to include students' participation in lesson and curriculum planning, classroom management, and other pedagogical involved tasks (Liu, Liu, \& Liu, 2018). Other studies even defined engagement in terms of interest, effort, motivation, time-on-task; the time student spent on a particular learning task (Bulger, Mayer, Almeroth, \& Blau, 2008). More recent concept of student 
engagement has placed much interest in the influence of school context, more specifically in the relationships between campus climate and students' experience of engagement (Dunleavy \& Milton, 2009; Martin, Wang, \& Sadaf, 2018).

A basic understanding of student engagement is that students' activity, involvement, and efforts in their learning tasks is related to their academic achievement (González, Talavera-Velasco, \& Gutiérrez, 2020). Krause and Coates (2008) mentioned that student engagement is the quality of effort students devote to educationally purposeful activities that directly contribute to desirable educational outcomes. In other words student engagement is the degree and quality, to which learners are engaged with their educational activities, which are positively linked to a host of desired outcomes, including high grades, student satisfaction, and perseverance (Kuh, Cruce, Shoup, Kinzie, \& Gonyea, 2008). In essence, the more students spend quality time and study a subject, the more they will know about it. Similarly, the more students interacts academically with faculties, the deeper they tend to understand what they are actually learning (Kuh, 2008).

\section{Dimensions of student engagement}

As mentioned earlier, student engagement seems to be multidimensional characteristically (Ben-Eliyahu, Moore, Dorph, \& Schunn, 2018). This nature of student engagement is reflected in the research literature (Fredricks et al., 2004). These scopes vary differently depending on the approaches used in studying student engagement. Majority of the studies in the literature focuses on either an individual or a combination of these dimensions. Most studies differentiate student engagement through their kinds, such as: Social engagement, Academic engagement, and Intellectual engagement (Dunleavy \& Milton, 2009). Besides, some researchers also distinguish student engagement in terms of the different behaviors of understanding the way students engage, such as: Behavioral engagement, Emotional engagement, and Cognitive engagement (Dunleavy \& Milton, 2009).

\section{Social engagement}

The National Research Council (2003) of the US noted that social engagement is the combination of the students' sense of belongingness at school, their feeling of connectedness and acceptance with classmates and peers, quality interaction with faculties, and their overall acknowledgement of the concept of schooling. Since, most researchers concluded that students who are disaffected (disengaged or the lack of engagement), tends to be bored, depressed, or even angry during class (Chapman, 2003). Similarly, disengaged students are said to be withdrawn from their peers, while some even exhibits rebellious behavior and go up against their teachers and other faculties (Kim, Lee, Leite, \& Huggins-Manley, 2020). In essence, students who feels socially isolated and fails to see the goals of schooling are more likely to not to function effectively ( $\mathrm{Hu}$ \& Hui, 2012).

\section{Academic and intellectual engagement}

Academic engagement is said to include the psychological investments and efforts toward learning, the mastery of skills and crafts, and the involvement in the diverse 
knowledge developing tasks (Zhen, Li, Ding, Hong, \& Liu, 2020). In academic engagement, it is important to regulate and understand what inspires students to participate in the compulsory tasks so as to realize school success (Robayo-Tamayo et al., 2020). Since, the most motivated and resilient students are said to be not the ones who think they have a lot of fixed or innate intelligence, but actually those who believe that their abilities can be developed through their effort and learning (Dweck \& Master, 2008). While intellectual engagement is said to be the serious emotional and cognitive investment in learning (Dunleavy \& Milton, 2009). Basically, in order to learn, what students both wants and needs are learning environments that are designed for deep intellectual engagement through which they can practice learning (Reeve, Cheon, \& Jang, 2020).

\section{Behavioural and emotional engagement}

Investigating the different ways how student engage, the idea of behavioral engagement comes from the idea of involvement (Fredricks et al., 2004). Such participations in academic and social activities, energetic attendance, assignments and exercise (task) completion, are all reflected as being crucial for achieving positive academic outcomes (Dunleavy \& Milton, 2009; Kuh, 2008). Behavioral engagement also encompasses the students' ability to follow rules and directions following classroom norms, on top of coming to class on time and avoiding unnecessary negative behaviors (Mih, Mih, \& Dragoş, 2015). Emotional engagement is the combination of the students' sense of belongingness, feeling of competence, and motivation towards the concept of schooling (Willms, 2003). It is also said to include the positive and negative reactions towards peers, teachers, administrators, and the school itself, these factors are all said to contribute to the students' willingness to participate (Fredricks et al., 2004).

\section{Cognitive engagement}

Cognitive engagement draws from the idea of investment (Fredricks et al., 2004). Studies mentioned that cognitive engagement consists of psychological investment in learning (Connell \& Wellborn, 1991). Some also mentioned that cognitive engagement is a desire to go beyond the minimum school requirements; a preference for challenge (Lamborn, Newmann, \& Wehlage, 1992). This is actually derived from Weiner's (1980) attribution theory, which mentioned that academic motivation in terms of task difficulty (or having the opportunity of a challenge) is one of the determining factors in the effort a student will expend on that activity. Since learning goals are set by the students themselves, therefore students seeking to improve their competence are likely to seek challenges and they tend to respond to failure by increasing their effort (Elliott \& Dweck, 1988). Such efforts could be further classified as the students' volition; the psychological control processes that protect concentration and directed effort in the face of personal and/or environmental distractions, and so aid learning and performance (Corno, 1993) which is said to be the underlying factor in going beyond the requirements in cognitive engagements (Fredricks et al., 2004). Research from new learning perspective of constructivism indicated that decline in engagement less pronounced in schools offering higher autonomy support and students attending schools with more supportive and accepting peers displayed less cognitive disengagement over time (Moreira \& Lee, 2020). 
Student engagement has been used to describe what college students are doing. Countless research has mentioned that students undergoing educationally purposeful activities are the single best predictor of academic and personal development (Pascarella \& Terenzini, 2005). Educationally purposeful activities are practices that encourage student engagement and foster learning (Pineda-Báez, Manzuoli, \& Sánchez, 2019). Chickering and Reisser (1993) mentioned in the "Seven Principles for Good Practice in Undergraduate Education" various practices that lead to high levels of student engagement. Such principles include student-faculty contact, cooperation among students, active learning, prompt feedback, time on task, high expectations, and respect for diverse talents and ways of learning.

Having caring and supporting relationships, sense of respect, fairness, trust, and a strong disciplinary climate are some of the factors that support effective student engagement (Dunleavy \& Milton, 2009). Similarly, the notion of academic press; high expectations for academic success, are supportive learning environments that promote competence and control In essence, students who are engaged show sustained behavioral involvement in learning activities accompanied by a positive emotional tone (Atif, Richards, Liu, \& Bilgin, 2020). More importantly, students that are engaged select tasks at the limit of their competencies, initiate action when given the opportunity, and shows positive emotions including enthusiasm, optimism, curiosity, and interest (Pietarinen, Soini, \& Pyhältö, 2014). In sum, student engagement is seen to comprise of various indicators such as active and collaborative learning, participation in challenging academic activities, formative communication with academic staff, involvement in enriching educational experiences, and feeling legitimated and supported by university learning communities (Coates, 2007).

\section{The present study}

As mentioned before, education practitioners view cooperation and engagement as a fundamental part of learning and the information building process. The acknowledgment of support is troublesome without connection, and comparatively, it is normal that communication happens in a situation where there is cooperation (Wenger, 1999, 2010). That is, each learner partaking in an online learning condition is really thought of as having a connection. Learner engagement in EFL classroom conversation in this manner is analysed against CMC in the present study.

To assess students' engagement and to distinguish successful community connections, there is a need to comprehend what conduct of behaviour students indicate while associating with group individuals, and what sorts of conduct are useful in organizing group work and in empowering others. Categorizing students' practices will represent social cooperation utilized for collaboration. Likewise, perception on how the social associations develop alongside the community oriented process will give a holistic picture of inside the group progression. Further, examinations of social interactions amongst more engaged and less engaged groups will clarify which practices could upgrade group conversation and engagement. This learning will enable educators to outline more compelling intercessions and to analyse the engagement procedure. To completely investigate and comprehend student engagement practices, this study will deliberately watch groups over a specified week time span. In the present study, learner engagement 
operationally deals with the progression of participants in conversation in terms of being transferred from limited engagement to elaborate engagement through scores and then students' patterns of engagement in face-to-face conversation and CMC are compared. How students' engagement patterns were explored was discussed was discussed in method section.

To this end, following research question was proposed:

1. Do face-to-face conversation and computer-mediated conversation significantly differ in the amount and levels of students' engagement?

\section{Method}

\section{Participants}

From among 86 Iranian male EFL intermediate participants from a language institute in Karaj province whose L1 was Persian, 30 participants were selected according to their proficiency level rated through OPT (Oxford Placement Test). Then, they were assigned into the research groups: face to face conversation and CMC. Each group consisted of 15 participants. There were five groups of three students in each group. Group assignment was based on participants' computer literacy. Participants with higher frequency of computer use on a daily basis and a high confidence in computer use (identified through related questions in their registration form for the program) were selected and assigned into CMC group. The rest of the participants were assigned into face-toface conversation group. This decreased bias and reduced the risk of placing either group at an advantage over the other one, and helped to mitigate the effect of preexisting differences regarding computer literacy (Hunsu, 2015). Informed consent was recognized and acknowledged in this research.

\section{Instrumentation}

The following instrumentations were used in this study. Oxford placement test was used to select homogeneous participants in terms of language proficiency. Topic familiarity questionnaire was used to select the familiar topics of discussion that participants find themselves confident at speaking. Online text chat forum with discussion options was designed and launched so that students' engagement levels could be traced through $\log$ analysis of the conversations of participants in computer mediated group.

\section{Oxford placement test}

OPT is standard test of language proficiency with a 6 rating scale. Students were rated according to the code of results interpretation displayed in Table 8 in Appendix A. The B1 and B2 level participants were selected to participate in this study.

\section{Topic familiarity questionnaire}

Topic familiarity is the understanding of a theme of a discussion, a discourse, a program, a piece of writing, a speech or the interest. There has been done some research about the topic familiarity and its colleague, background knowledge (Mohamadi, 2018a; Mohammadi, 2017) Prior to task administration, the participants were asked to fill in a topic familiarity questionnaire. This test measured their prior knowledge on the topic 
of the task. The researcher developed the questionnaire in order to find out to what extent the participants are familiar with the topic. The questionnaire included 10 item on three level likert scale of A) Very familiar: 3 points, B) Familiar: 2 points, C) Not familiar: 1 point. The topics with highest frequency of being selected by the participants were on the basis of which tasks were designed. Social issues such as 'divorce', 'poverty', 'addiction', 'crime', and 'unemployment' were selected to be used in this study on the basis of the candidates' answers to the topic familiarity questionnaire which accounted for $64 \%$ of the selected topics. Other topics concerned celebrities (12\%), education (10\%), and traveling (14\%). The topics with highest percentage of being selected were included in the study.

\section{Online text chat forum}

For measuring student engagement in CMC an online e- writing forum was designed and launched on http//e-writingforum.ir on September 2016. Some of the features of this website are as follow; (1) Sharing with anyone in such a way that no finished file is uploaded; (2) accept or reject changes which means the possibility of tracking the changes and making control of what makes into the writing tasks and what does not; (3) in line comments which are provided through collaboration on specific pieces of text; (4) Discussion tools by which participants could share ideas, review changes and gather feedback in one place. The website was introduced both to teachers and ecollaborative writing group students. Students were instructed about how to create an account. Teachers were also instructed about how to act as admins and use the potential and informative options provided by the website to monitor group work.

\section{Materials}

To conduct the present study, the researcher designed the discussion task and submitted them to two teachers for adaptation, revision and evaluation. Task appropriateness and task content consistency and complexity were the criteria in designing tasks and in keeping consistency across the groups. The intraclass correlation coefficient was computed in order to probe the inter-rater reliability of the two raters who rated the appropriacy of task with respect to the participants. The results indicated that there was a significant agreement between the two raters $(\mathrm{a}=.765, p<.01,95 \% \mathrm{CI}[.556, .876])$. The sample task is given in Appendix B.

\section{Procedure}

This section provides information on procedure in conducting the present research. It provides information on procedure for data collection phase and procedure for data analysis phase.

\section{Procedure for data collection}

To build concepts from a textual data source (conversations on online text chats forum and transcription of conversations in CMC and face-to-face conversation), the texts needed to be opened up to explore the meaning, idea and thoughts in it. One of the processes of analyzing textual content is Open Coding. Open Coding includes labeling concepts, defining and developing categories based on their properties and dimensions. 
The guidelines of Creswell and Guetterman (2019) is used to analyze qualitative data and part of many Qualitative Data Analysis methodologies. Different parts of the data were marked with appropriate labels or 'codes' to identify them for further analysis. A concept is a labeled section of data that a researcher identifies as significant to some facts that data represent. Concepts are abstract representations of events, objects, actions or interactions and they allow researchers to group similar information to better understand the data. The derived codes on Maxqda software included L1 use vs. avoidance, appeal for help, hesitations, long pauses, and silence vs. strategic management of conversation, focus on syntax level vs. focus on discourse, mere compliance with the task or moving far from the task requirement, gestures showing uncertainty. The map is presented in Fig. 1 and Appendix C.

On the basis of coded concepts driven from episode analysis of transcription of in $\mathrm{CMC}$ and face- to- face conversation, learners' engagement was operationally defined as the progression of participants in conversation in terms of being transferred from limited engagement to elaborate engagement through scores. The progression was specified in Table 1 and used as rating scheme for data analysis (Mohamadi, 2017).

The teachers were instructed to code behavioural, affective and cognitive limited and elaborate limited engagement at three levels of verbal, paralinguistic and functional. The teachers looked for evidences of engagement and for (counter) evidences of what contributes to limited and elaborate engagement. They differentiated less and more important evidences and assign score and specified if entire performance could be attributed to specific level of engagement. Then they wrote a brief summary in which comments on codes were given and important arguments and evidences were cited. They consulted follow teacher and compared the assigned code with each other. Then, they discussed about the assigned codes and the rationale by providing evidences and arguments. On the basis of their discussion, they decided whether to hold on to the original code or make adjustments. The intraclass correlation coefficient was computed in order to probe the inter-rater reliability of the two raters who rated the participants'

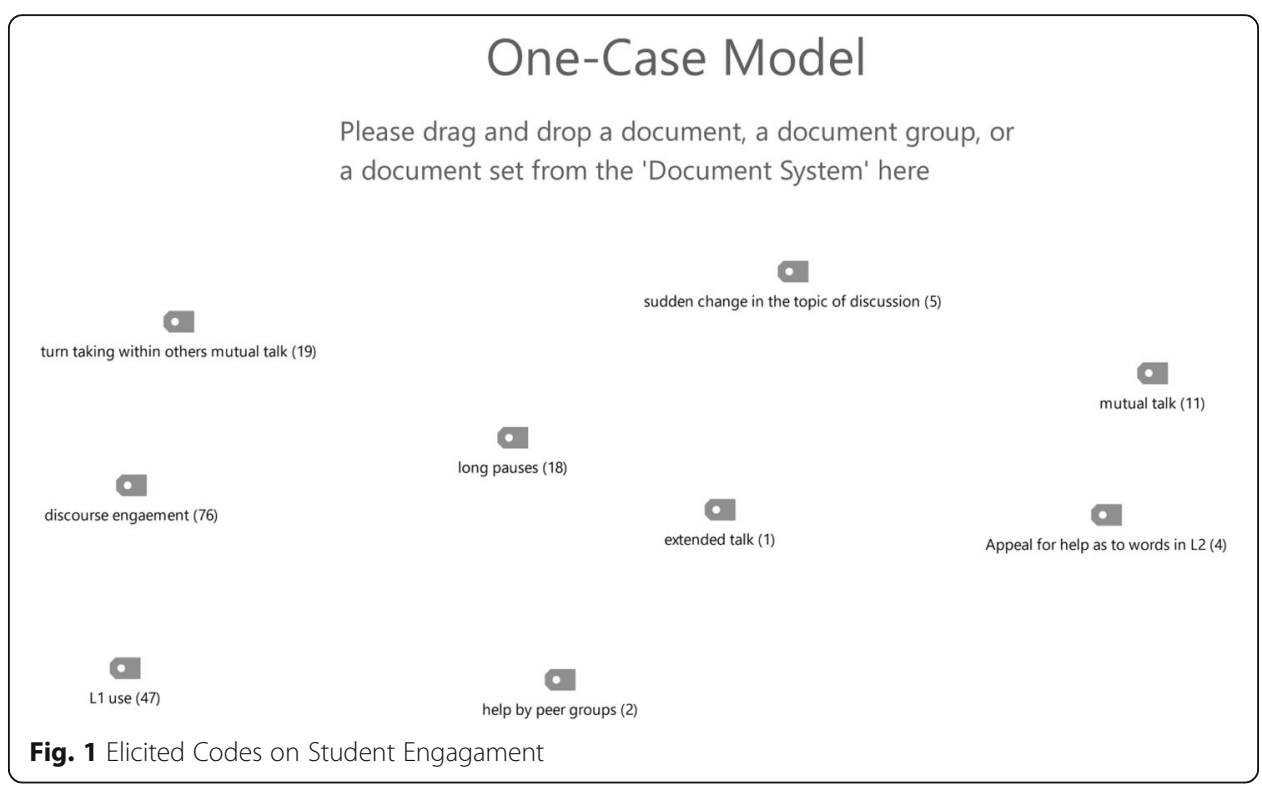


Table 1 The trend of change in task engagement over discussion task

\begin{tabular}{|c|c|}
\hline Limited engagement & Elaborate engagement \\
\hline \multicolumn{2}{|l|}{ Verbal Level } \\
\hline 1. L1 use & 1. No L1 use \\
\hline 2. Engagement at the level of syntax & 2. Engagement at the level of discourse \\
\hline 3. Procedural talk & 3. Actual talk \\
\hline 4. Mere compliance with the requirements of the task & $\begin{array}{l}\text { 4. No tendency to finish the task and provide } \\
\text { information beyond the requirements of the task }\end{array}$ \\
\hline 5. Appeal for help from reference books or teacher & 5. coining words and the use of strategic Competence \\
\hline \multicolumn{2}{|l|}{ Paralinguistic Level } \\
\hline 1.Presence of silence & 1.Absence of silence \\
\hline 2.Long pauses, hesitations and laughs & 2.More fluent language use \\
\hline \multicolumn{2}{|l|}{ Functional Level } \\
\hline 1. Appeal for help from the teacher & 1.No more reliance on the teacher and students \\
\hline \multirow[t]{3}{*}{ 2. Gestures showing uncertainty } & 2.provide their own justification even in L1 \\
\hline & 3.Gestures showing satisfaction with task performance \\
\hline & 4.Arguments between the partners almost like a fight \\
\hline
\end{tabular}

performance on posttest. The results indicated that there was a significant agreement between the two raters $(\mathrm{a}=.812, p<.01,95 \%$ CI $[.645, .901])$.

In order to avoid losing important data especially the nonverbal aspects of the original communication situation such as body language which are especially important at behavioural engagement analysis, the researcher attended the discussion sessions as a non-participatory observer to track the nonverbal indicators. This was avoided in CMC group acknowledged as limitations of the study.

\section{Procedure for data analysis}

After selecting the participants and materials, the researcher asked each group to discuss the prompt in the task in both groups of face-to-face group and CMC group. Task instructions were given in their L1 to avoid any misunderstanding in how the task should be performed. The participants' performances across the task were audio recorded and transcribed for further analysis in face-to face group. In CMC group, the logs of online text chats forum were printed as transcriptions. The transcriptions were given to the raters to code the evidences for behavioural, cognitive limited and elaborate engagement. This is an exploratory descriptive investigation of the potential of two speaking modalities of CMC and face-to-face conversation in discussion task. The chisquare analysis was used to answer the research question.

\section{Results}

To answer the research question which is investigating the potential of two speaking modalities; face-to face conversation and CMC in engaging students and leading them from limited engagement to elaborate engagement, a series of chi-square analyses was used. Table 2 indicated the frequencies of incidences of limited engagement in face-toface conversation and CMC groups (Fig. 2). 
Table 2 Frequency, Percentage and Std. Residual of Limited Engagement by Groups

\begin{tabular}{|c|c|c|c|c|c|}
\hline & & & \multicolumn{2}{|l|}{ Group } & \multirow[t]{2}{*}{ Total } \\
\hline & & & face-to-face & CMC & \\
\hline \multirow[t]{27}{*}{ Types } & \multirow[t]{3}{*}{ L1 use } & Count & 32 & 84 & 116 \\
\hline & & $\%$ within Types & $27.6 \%$ & $72.4 \%$ & $100.0 \%$ \\
\hline & & Standardized Residual & -3.2 & 3.1 & \\
\hline & \multirow[t]{3}{*}{ Engagement Syntax } & Count & 98 & 180 & 278 \\
\hline & & $\%$ within Types & $35.3 \%$ & $64.7 \%$ & $100.0 \%$ \\
\hline & & Standardized Residual & -3.1 & 3.0 & \\
\hline & \multirow[t]{3}{*}{ Procedural Talk } & Count & 168 & 100 & 268 \\
\hline & & $\%$ within Types & $62.7 \%$ & $37.3 \%$ & $100.0 \%$ \\
\hline & & Standardized Residual & 3.4 & -3.3 & \\
\hline & \multirow[t]{3}{*}{ Mere compliance } & Count & 85 & 58 & 143 \\
\hline & & $\%$ within Types & $59.4 \%$ & $40.6 \%$ & $100.0 \%$ \\
\hline & & Standardized Residual & 1.9 & -1.9 & \\
\hline & \multirow[t]{3}{*}{ Appeal for help Reference Book } & Count & 26 & 37 & 63 \\
\hline & & $\%$ within Types & $41.3 \%$ & $58.7 \%$ & $100.0 \%$ \\
\hline & & Standardized Residual & -.8 & .8 & \\
\hline & \multirow[t]{3}{*}{ Presence of Silence } & Count & 18 & 50 & 68 \\
\hline & & $\%$ within Types & $26.5 \%$ & $73.5 \%$ & $100.0 \%$ \\
\hline & & Standardized Residual & -2.6 & 2.5 & \\
\hline & \multirow[t]{3}{*}{ Long pauses Hesitation } & Count & 37 & 26 & 63 \\
\hline & & $\%$ within Types & $58.7 \%$ & $41.3 \%$ & $100.0 \%$ \\
\hline & & Standardized Residual & 1.2 & -1.2 & \\
\hline & \multirow[t]{3}{*}{ Appeal for help from teacher } & Count & 22 & 2 & 24 \\
\hline & & $\%$ within Types & $91.7 \%$ & $8.3 \%$ & $100.0 \%$ \\
\hline & & Standardized Residual & 3.1 & -3.0 & \\
\hline & \multirow[t]{3}{*}{ Gesture showing Uncertainty } & Count & 15 & 0 & 15 \\
\hline & & $\%$ within Types & $100.0 \%$ & $0.0 \%$ & $100.0 \%$ \\
\hline & & Standardized Residual & 2.9 & -2.8 & \\
\hline \multirow[t]{2}{*}{ Total } & & Count & 501 & 537 & 1038 \\
\hline & & $\%$ within Types & $48.3 \%$ & $51.7 \%$ & $100.0 \%$ \\
\hline
\end{tabular}

The results of analysis of chi-square $\left(\chi^{2}(8)=119.31, p=.000, r=.339\right.$ representing a moderate effect size) (Table 3 ) indicated that there were significant differences between the face-to-face and CMC conversations in terms of limited engagement.

Table 4 indicates the frequencies of elaborate engagement indicators in face-to face conversation and CMC groups.

The CMC group (57.9\%; Std. Residual = $2.6>1.96$ ) significantly had "no reliance on the teacher and students" than the face-to-face group (42.1\%; Std. Residual $=-2.5>$ $-1.96)$ group. The face-to-face group (100\%; Std. Residual $=5.3>1.96)$ significantly showed more "gestures showing satisfaction with task performance" than CMC group $(0 \%$; Std. Residual $=-5.7>-1.96)$ group. And finally; the CMC group (63.8\%; Std. Residual $=2.5>1.96$ ) significantly had more "arguments between partners almost like a fight" than the face-to-face group (36.2\%; Std. Residual $=-2.4>-1.96$ ) group implying 


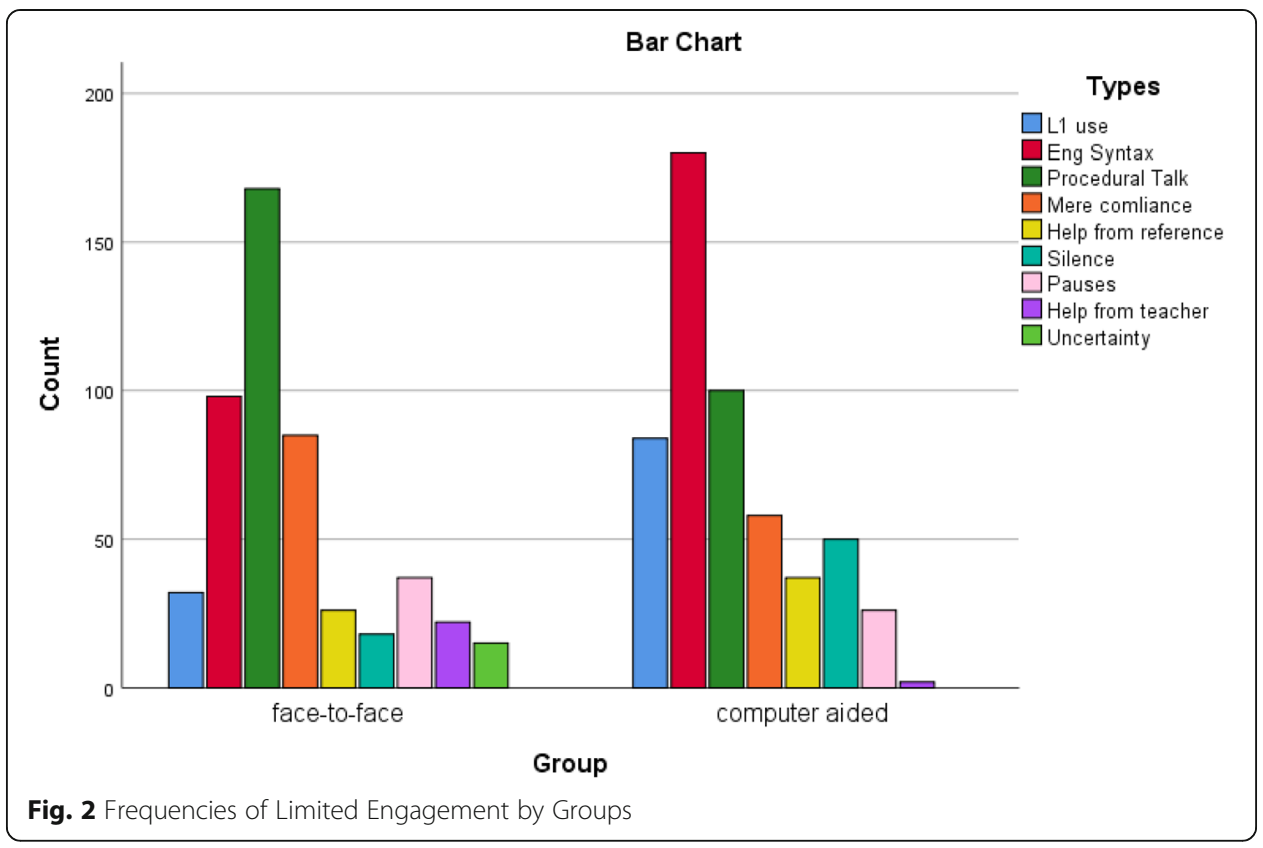

that the in CMC group students move far from the task requirement than mere compliance with the task (Fig. 3).

The results of analysis of chi-square $\left(\mathrm{X}^{2}(9)=146.62, p=.000, r=.285\right.$ representing an almost moderate effect size) (Table 5) indicated that there were significant differences between the face-to-face and mobile aided groups' elaborated engagement.

Table 6 displays the frequency, percentage and Std. Residual of the face-to-face and $\mathrm{CMC}$ groups engaging in limited and elaborated situations. Although CMC showed more limited engagement $(56 \%$; Std. Residual $=1.4<1.96)$ than the face-to-face group (44\%; Std. Residual $=-1.5<-1.96)$, the difference was not statistically significant. Although the face-to-face group showed more elaborated engagement (48.8\%; Std. Residual $=1.1<1.96)$ than CMC $(51.2 \%$; Std. Residual $=-1.1<-1.96)$, the difference was not statistically significant.

The results of analysis of chi-square $\left(\mathrm{X}^{2}(1)=6.32, p=.012, r=.045\right.$ representing a weak effect size) (Table 7) indicated that there were significant differences between the face-to-face and CMC groups' elaborated and limited engagements, although the results should be interpreted cautiously due to the weak effect size value of .045 (Fig. 4).

\section{Discussion}

This descriptive exploratory research investigated the indicators on limited and elaborate engagement and they were categorized as verbal level, paralinguistic and functional

Table 3 Chi-Square Tests; Limited Engagement by Groups

\begin{tabular}{llll}
\hline & Value & df & Asymptotic Significance (2-sided) \\
\hline Pearson Chi-Square & $119.311^{\text {a }}$ & 8 & .000 \\
Likelihood Ratio & 129.865 & 8 & .000 \\
Linear-by-Linear Association & 31.745 & 1 & .000 \\
N of Valid Cases & 1038 & & \\
\hline
\end{tabular}

a 0 cells $(0.0 \%)$ have expected count less than 5 . The minimum expected count is 7.24 
Table 4 Frequency, Percentage and Std. Residual of Elaborated Engagement by Groups

\begin{tabular}{|c|c|c|c|c|c|}
\hline & & & \multicolumn{2}{|l|}{ Group } & \multirow[t]{2}{*}{ Total } \\
\hline & & & face-to-face & computer aided & \\
\hline \multirow[t]{30}{*}{ Types } & \multirow[t]{3}{*}{ No L1 use } & Count & 124 & 130 & 254 \\
\hline & & $\%$ within Types & $48.8 \%$ & $51.2 \%$ & $100.0 \%$ \\
\hline & & Standardized Residual & -.9 & 1.0 & \\
\hline & \multirow{3}{*}{$\begin{array}{l}\text { Engagement } \\
\text { Discourse }\end{array}$} & Count & 57 & 73 & 130 \\
\hline & & $\%$ within Types & $43.8 \%$ & $56.2 \%$ & $100.0 \%$ \\
\hline & & Standardized Residual & -1.4 & 1.5 & \\
\hline & \multirow[t]{3}{*}{ Actual Talk } & Count & 133 & 69 & 202 \\
\hline & & $\%$ within Types & $65.8 \%$ & $34.2 \%$ & $100.0 \%$ \\
\hline & & Standardized Residual & 2.5 & -2.6 & \\
\hline & \multirow{3}{*}{$\begin{array}{l}\text { No Tendency } \\
\text { To finish task }\end{array}$} & Count & 107 & 84 & 191 \\
\hline & & $\%$ within Types & $56.0 \%$ & $44.0 \%$ & $100.0 \%$ \\
\hline & & Standardized Residual & 6 & -.6 & \\
\hline & \multirow[t]{3}{*}{ Coining words } & Count & 47 & 1 & 48 \\
\hline & & $\%$ within Types & $97.9 \%$ & $2.1 \%$ & $100.0 \%$ \\
\hline & & Standardized Residual & 4.3 & -4.5 & \\
\hline & \multirow[t]{3}{*}{ Absence of silence } & Count & 139 & 140 & 279 \\
\hline & & $\%$ within Types & $49.8 \%$ & $50.2 \%$ & $100.0 \%$ \\
\hline & & Standardized Residual & -.7 & .8 & \\
\hline & \multirow[t]{3}{*}{ Fluent language } & Count & 128 & 125 & 253 \\
\hline & & $\%$ within Types & $50.6 \%$ & $49.4 \%$ & $100.0 \%$ \\
\hline & & Standardized Residual & -.5 & 6 & \\
\hline & \multirow[t]{3}{*}{ No Reliance } & Count & 112 & 154 & 266 \\
\hline & & $\%$ within Types & $42.1 \%$ & $57.9 \%$ & $100.0 \%$ \\
\hline & & Standardized Residual & -2.5 & 2.6 & \\
\hline & \multirow{3}{*}{$\begin{array}{l}\text { Satisfaction } \\
\text { with performance }\end{array}$} & Count & 69 & 0 & 69 \\
\hline & & $\%$ within Types & $100.0 \%$ & $0.0 \%$ & $100.0 \%$ \\
\hline & & Standardized Residual & 5.3 & -5.7 & \\
\hline & \multirow[t]{3}{*}{ argue parents } & Count & 38 & 67 & 105 \\
\hline & & $\%$ within Types & $36.2 \%$ & $63.8 \%$ & $100.0 \%$ \\
\hline & & Standardized Residual & -2.4 & 2.5 & \\
\hline \multirow[t]{2}{*}{ Total } & & Count & 954 & 843 & 1797 \\
\hline & & $\%$ within Types & $53.1 \%$ & $46.9 \%$ & $100.0 \%$ \\
\hline
\end{tabular}

levels. Then, the potential of two speaking modalities of face-to face conversation and $\mathrm{CMC}$ in engaging students was examined. To this end, the progression from limited to elaborate engagement at verbal, paralinguistic and functional levels of 30 Iranian intermediate male students in conversation was assessed. The transcription analysis of face to face conversation and log analysis of computer mediated conversation via Maxqda software led to the identification of limited and elaborate student engagements in two modalities indicators. The derived codes on Maxqda software included L1 use vs. avoidance, appeal for help, hesitations, long pauses, and silence vs. strategic management of conversation, focus on syntax level vs. focus on discourse, mere compliance with the task or moving far from the task requirement, gestures showing uncertainty. 


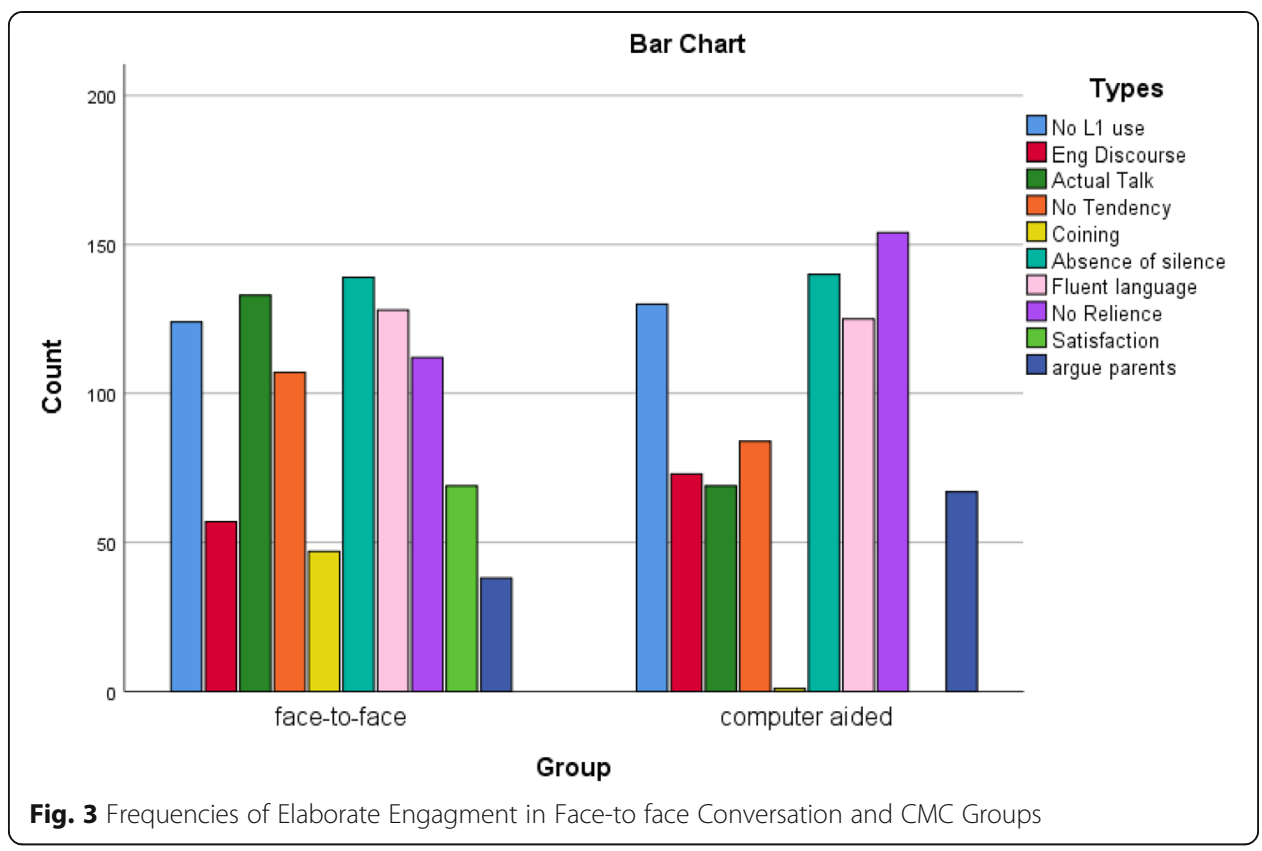

While limited engagement was associated with appeal for help, silence, pauses and hesitations, focus on syntax, involvement with procedural talk and L1 use, elaborate engagement was associated with avoiding L1 use, focus on discourse, involvement with actual talk and strategic management rather than pause and silence. Occurrence of each indicator was treated as a test score and chi-square analysis on frequency of indictors of limited and elaborate engagements on verbal, paralinguistic and functional levels indicated that two speaking modalities had significantly different potential in engaging students.

Chi square analysis indicated that limited student engagement was more seen in CMC groups that face-to-face group. L1 use, attention to syntax, appeal for help and silence were limited engagement indicators more apparent in CMC conversations. Long pauses, hesitations and laughs and appeal for help from teachers were significantly farther in face-to-face group. The same analysis for elaborated student engagement indicated that there were statistically significant differences in elaborate engagement of CMC and face-to-face group. L1 use, more actural talk than procedural talk, more coined words in face-to-face conversation was found compared to CMC one. CMC group outperformed face-to-face group in elaborate student engagement in terms of students' attention to discourse. As far as silence and fluent language were considered, no significant difference was found between the groups.

Table 5 Chi-Square Tests; Elaborated Engagement by Groups

\begin{tabular}{llll}
\hline & Value & df & Asymptotic Significance (2-sided) \\
\hline Pearson Chi-Square & $146.624^{\mathrm{a}}$ & 9 & .000 \\
Likelihood Ratio & 185.951 & 9 & .000 \\
Linear-by-Linear Association & .635 & 1 & .426 \\
N of Valid Cases & 1797 & & \\
\hline
\end{tabular}

${ }^{\mathrm{a}} 0$ cells $(0.0 \%)$ have expected count less than 5 . The minimum expected count is 22.52 
Table 6 Frequency, Percentage and Std. Residual of Elaborated vs. Limited Engagement by Groups

\begin{tabular}{|c|c|c|c|c|c|}
\hline & & & \multicolumn{2}{|l|}{ Group } & \multirow[t]{2}{*}{ Total } \\
\hline & & & Computer Aided & Face-to-face & \\
\hline \multirow[t]{6}{*}{ Type } & limited & Count & 637 & 501 & 1138 \\
\hline & & \% within Type & $56.0 \%$ & $44.0 \%$ & $100.0 \%$ \\
\hline & & Standardized Residual & 1.4 & -1.5 & \\
\hline & elaborated & Count & 953 & 909 & 1862 \\
\hline & & \% within Type & $51.2 \%$ & $48.8 \%$ & $100.0 \%$ \\
\hline & & Standardized Residual & -1.1 & 1.1 & \\
\hline \multirow[t]{2}{*}{ Total } & & Count & 1590 & 1410 & 3000 \\
\hline & & \% within Type & $53.0 \%$ & $47.0 \%$ & $100.0 \%$ \\
\hline
\end{tabular}

, The findings of this study are consistent with one main study carried out in the realm of maximizing learning opportunities by investigating the potential of four different task types (translation, dictogloss, text reconstruction and jigsaw) (Mohamadi, 2017). In proportion to her study, how individuals are engaged with language in collaborative tasks was assessed in the present research, focusing on learner engagement in EFL learner's face-to-face conversation vs. CMC.

At verbal level, it could be mentioned that Heidari-Shahreza (2014) investigated the effect of content-based language instruction on EFL learners' engagement and verbal interaction. He analyzed the scheme-based classroom observation for a whole semester to find that the students in the verbal, content-based class were engaged in and volunteered for learning tasks and activities more than their counterparts in the languagebased class did. Also, Khabiri and Khatibi's (2013) study revealed some innovative uses of mobile devices in terms of verbal engagement. All in all showed consistency in the findings indicated in the present study.

Para-linguistically speaking, Gholamshahi and Pazhakh (2016) investigated the extent explicit teaching of paralinguistic cues including YouTube, Podcast and mobile phones contributed to developing EFL learners' paralinguistic performance in speaking skills/ abilities in terms of paralinguistic cues such as intonation, pitch, stress, and sonority. They did the study on 64 Persian young natives at intermediate level, who formed the sample after randomly dividing them into four equal groups, three experimental groups and one control group. Their study showed significant differences in favor of all experimental groups.

Table 7 Chi-Square Tests; Elaborated vs. Limited Engagement by Groups

\begin{tabular}{llllll}
\hline & Value & df & $\begin{array}{l}\text { Asymptotic Significance } \\
\text { (2-sided) }\end{array}$ & $\begin{array}{l}\text { Exact Sig. } \\
\text { (2-sided) }\end{array}$ & $\begin{array}{l}\text { Exact Sig. } \\
\text { (1-sided) }\end{array}$ \\
\hline Pearson Chi-Square & $6.516^{\mathrm{a}}$ & 1 & .011 & & \\
Continuity Correction $^{\mathrm{b}}$ & 6.325 & 1 & .012 & .012 & .006 \\
Likelihood Ratio & 6.525 & 1 & .011 & & \\
Fisher's Exact Test & & & & .011 & \\
Linear-by-Linear Association & 6.514 & 1 & & \\
N of Valid Cases & 3000 & & &
\end{tabular}

${ }^{\mathrm{a}} 0$ cells $(0.0 \%)$ have expected count less than 5 . The minimum expected count is 534.86 .

${ }^{b}$ Computed only for a $2 \times 2$ table 


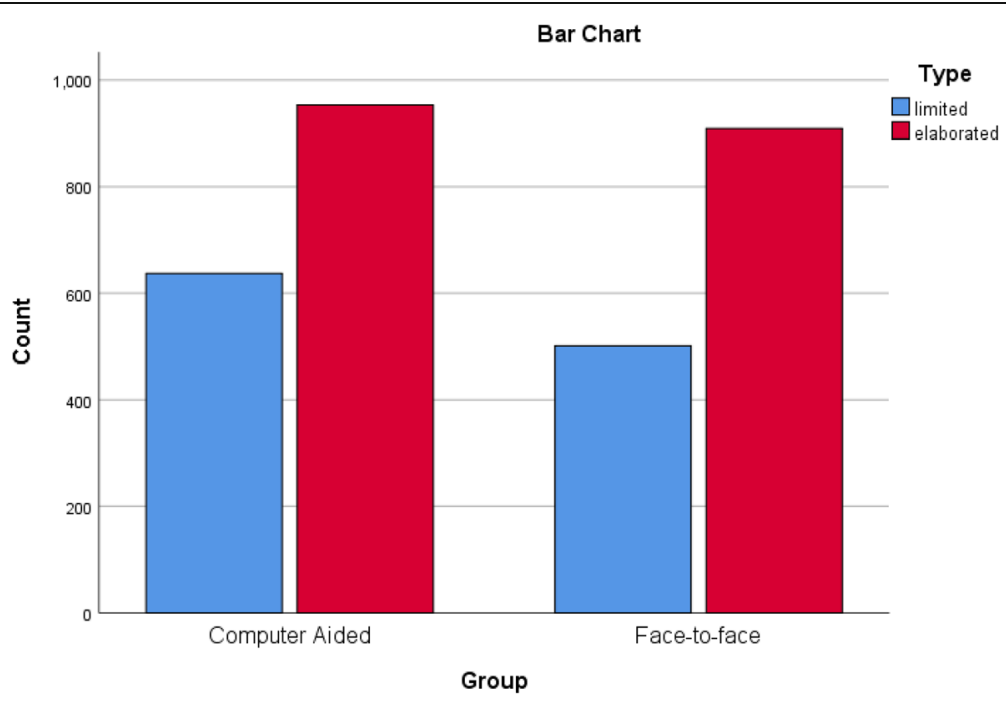

Fig. 4 Frequencies of Elaborate and Limited Engagement in Face-to-face and CMC Conversations

At functional level, there were also other studies done in quite the same area; Morett, Gibbs and MacWhinney (2016) investigated gestures of L2 learners in communicating in conversational situations. They also wanted to see whether their gesturing in these settings facilitated L2 acquisition beyond the instant environment. Their findings showed that L2 learners created more iconic gestures when their interlocutor was visible, and that gesture production forecasted their recall for novel words introduced in conversation. They also showed that conversational gesturing facilitated language communication, acquisition, and retention.

The results of this study also corroborate a number of much recent studies. For example, Snijders et al. (2020) in their study of student engagement dimensions such as relationship quality and affective commitment act as mediators of student engagement. Education modality is one among the factors that may mediate between the two. Likewise, Galikyan and Admiraal (2019) studied students' engagement in asynchronous online discussion. Their findings suggest that online discourse reflects the level of cognitive engagement in teacher education courses, engagement in integration and resolution significantly predicts academic performance, centrality moderates the relationship between resolution and learner academic performance, and learner interactions enhances understanding of knowledge building. In line with aforementioned study, the findings of the present study also suggest that face-toface modality enhances centrality which in turn boosts cognitive engagement. Contradictory to the aforementioned study, the present study suggest learner interaction enhancing knowledge building more in face-to-face conversation compared to online one., $\mathrm{Xu}$, Chen, and Chen (2020) studied the effects of teacher role on student engagement in WeChat-Based online discussion learning. The results indicated that teacher role facilities student cognitive and behavioral engagement but not emotional engagement. Contradictorily, the results of the present study were in the favor of face-to-face conversation as far as cognitive, behavioral and emotional engagements were considered. The results of the present study also contracted the results of the study by Wolverton (2018). In her study of utilizing synchronous discussions to create an engaged classroom in online executive education, she approved the potential of synchronous distance learning in engaging students. The implication suggested by the results of the present study in general is favoring enhancement of student 
interaction and peer collaboration and teacher emotional support; the factors that were confirmed by similar study by (Pineda-Báez et al., 2019). Likewise, student disengagement was discovered to be declined via teacher and school support (Moreira \& Lee, 2020). This was supported by the results of the present study suggesting that as students 's appeal for help and teachers' providing assistance faded away as students were elaborately engaged with the school activities.

There was a key advantage of for this research and that is the algorithm chosen in data collection and analysis was not predetermined. The incidences of limited and elaborate engagement in two speaking modalities were discovered through conversation analysis of recorded transcriptions and logs as they were emerged in student talk. Therefore, no important rule occurring in both mediums is obscured and missed. Besides, researchers and educators continuously remark the importance of integrating creativity into the learning process (Chen \& Chiu, 2016; MurilloZamorano et al., 2019). This study proposes a creative approach to facilitate participatory learning for the sustained engagement of young learners based on the principle of remix practice, which consists of learning to generate online artifacts, endless hybridization and scaffolding (Liu, Chen, Lin, \& Huang, 2017). This study was a comparative study studying online artifacts compared to actual ones in promoting student engagement.

\section{Concluding remarks}

The purpose of this study was to assess learners' engagement in an EFL setting through face-to-face vs. CMC conversations. For this purpose, the researcher conducted the current study on five groups of three students both in face-to-face classroom conversation and CMC through online text chat forum. The participants' performances across speaking were recorded and transcribed for data analysis. The transcription in face-to-face conversation and log analysis in online text chat forum was reviewed and indicators of limited and elaborate engagement at verbal, paralinguistic and functional levels were identified via Maxqda software. The indicators of limited and elaborate engagement were coded according to a coding template mentioned in the procedure section. The results of chi-square indicated that there were significant differences between the face-to-face and CMC groups' limited engagement.

The derived codes on Maxqda software included L1 use vs. avoidance, appeal for help, hesitations, long pauses, and silence vs. strategic management of conversation, focus on syntax level vs. focus on discourse, mere compliance with the task or moving far from the task requirement, gestures showing uncertainty. While limited engagement was associated with appeal for help, silence, pauses and hesitations, focus on syntax, involvement with procedural talk and L1 use, elaborate engagement was associated with avoiding L1 use, focus on discourse, involvement with actual talk and strategic management rather than pause and silence. As mentioned earlier, the incidences of limited and elaborate engagements occur with different proportions in face-to-face and CMC conversations. The findings of the study illustrate how students' engagement in learning evolves and how speaking modalities may impact the pattern of students' engagement over time.

However, as noted previously, we could not rule out the possibility that unmeasured classroom or CM factors could have influenced students' task engagement such as teacher 
effects, infrastructure inconveniences such as internet quality and speed. Thus, caution is required when considering a causal interpretation of the relationship between speaking modalities and student engagement. This study was conducted with a small number of participants, which may have impacted the power of the statistical analyses. Moreover, having no control group in decreases the strength of the arguments about the effectiveness of speaking modalities on student engagement. Therefore, future studies should be conducted with a larger sample size, and a control group should be included to test the effectiveness of speaking modalities on student engagement $t$ in a more solid way.

Despite these limitations, this study has several implications for theory and practice. First, the findings provided insights into measurement of student engagement in a multidimensional sense where student engagement is measured from verbal, paralinguistic and functional dimensions. To recapitulate, the current study establishes a link between speaking modalities and students' subsequent engagement in a collaborative activity. Formal education is restricted by the pre-defined curriculum which requires that students attain certain knowledge. Yet, the acquisition of that knowledge may restrict the creative process. Many studies have pointed out the significant contrast between the creative nature of participatory learning activities and the structured learning that takes place in schools (Liu et al., 2017). The findings support the hypothesis that modality through which a task is accomplished affects the output. In terms of practical implications, this study suggests that student engagement can still be moderated. One possible approach to improving student engagement without overintervening of teachers is using modalities such as forums where the teacher presence is limited and students have to manage the discourse themselves which in turn increases student engagement (Baker et al., 2017).

\section{Appendix A}

Table 8 OPT code of interpretation

\begin{tabular}{lll}
\hline Indicator & Proficiency level & Description \\
\hline A1 & Basic & scores fell between 0 and 17 \\
A2 & Elementary students & scores were $18-29$ \\
B1 & Lower intermediate & scores between 30 and 39 \\
B2 & Upper-intermediate & scores between 40 and 47 \\
C1 & Advance & scores between 48 and 54 \\
C2 & Very advance & Scores between 54 and 60 \\
\hline
\end{tabular}

\section{Appendix B}

\section{A Sample Discussion Task}

Suppose an elderly man is experiencing the final days of his life. He is wealthy. His total wealth is 200 million dollars and he is willing to give you half of his money, if you manage to solve, eradicate or improve one or several social disorders, what social disorders would you consider eliminating? How would you take actions? What damages are being made by a social disorder of your interest? Can it be eradicated? 


\section{Appendix C}

The dervived codes from face to face and CMC collaborations

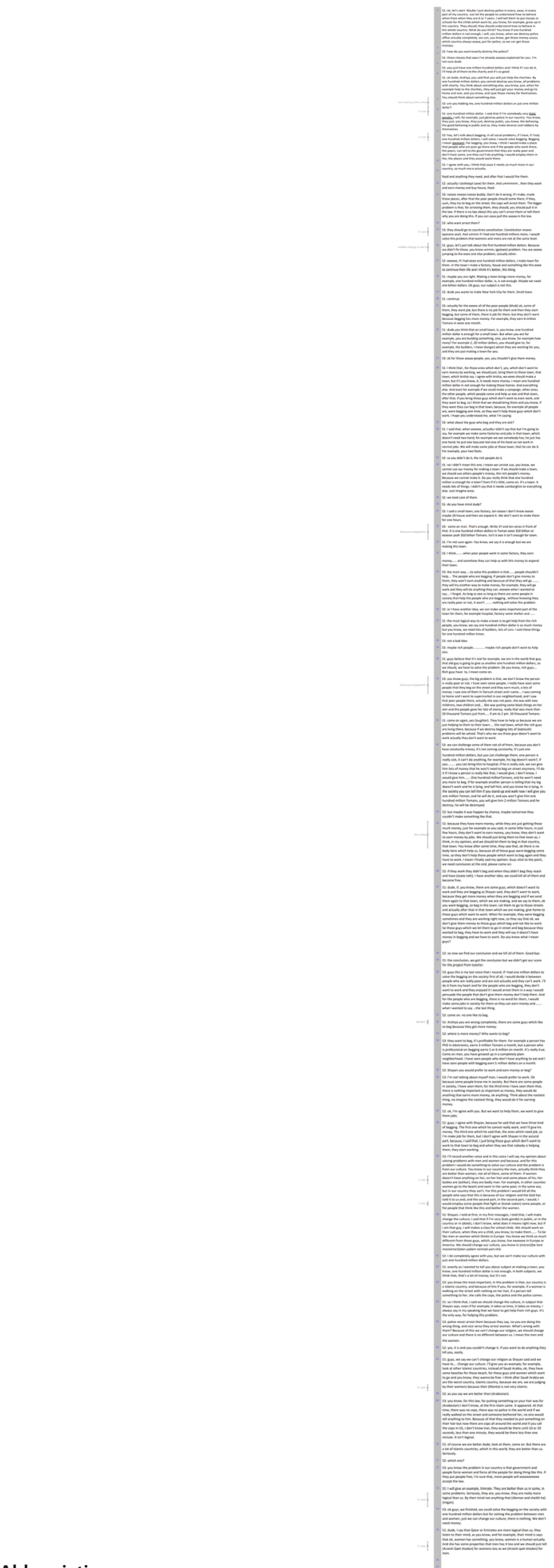




\section{Acknowledgments}

The authors acknowledge all the individuals who participated in this study.

\section{Authors' contributions}

To achieve the purpose of the study, ZMZ conceived of the study, and participated in its design and coordination and performed the statistical analysis and help the final draft of the manuscript. MB conceived of the study and participated in its design and data collection and help final draft of the study. Both authors read and approved the final manuscript.

Funding

There is no funding for this research.

\section{Availability of data and materials}

Data is available for submission if required through anonymous email.

\section{Competing interests}

There is no conflicting interest.

Received: 24 June 2020 Accepted: 11 November 2020

Published online: 18 January 2021

\section{References}

Agudo, J. d. D. M. (2019). Which instructional programme (EFL or CLIL) results in better oral communicative competence? Updated empirical evidence from a monolingual context. Linguistics and Education, 51, 69-78.

Ansarin, A. A., \& Mohamadi, Z. (2013a). Language engagement at the level of syntax: Assessing Metatalk and task types in SLA. International Journal of Applied Linguistics and English Literature, 2(4), 142-154.

Ansarin, A. A., \& Mohamadi, Z. (2013b). Language engagement in task-based interaction: Focus on intonation. The Iranian EFL Journal, 12(2), 152

Atif, A., Richards, D., Liu, D., \& Bilgin, A. A. (2020). Perceived benefits and barriers of a prototype early alert system to detect engagement and support 'at-risk'students: The teacher perspective. Computers \& Education, 156, 103954.

Baker, A. R., Lin, T.-J., Chen, J., Paul, N., Anderson, R. C., \& Nguyen-Jahiel, K. (2017). Effects of teacher framing on student engagement during collaborative reasoning discussions. Contemporary Educational Psychology, 51, 253-266.

Bataineh, R. F., \& Hani, N. A. B. (2011). The effect of a call program on Jordanian sixth-grade students'achievement. Teaching English with Technology, 11(3), 3-24.

Batianeh, A. M. (2014). The effect of text chat assisted with word processors on Saudi English major Students' writing accuracy and productivity of authentic texts. International Journal of Emerging Technologies in Learning (iJET), 9(9), 32-40.

Ben-Eliyahu, A., Moore, D., Dorph, R., \& Schunn, C. D. (2018). Investigating the multidimensionality of engagement: Affective, behavioral, and cognitive engagement across science activities and contexts. Contemporary Educational Psychology, 53, $87-105$.

Bulger, M. E., Mayer, R. E., Almeroth, K. C., \& Blau, S. D. (2008). Measuring learner engagement in computer-equipped college classrooms. Journal of Educational Multimedia and Hypermedia, 17(2), 129-143.

Burkett, E. (2002). Another planet: A year in the life of a suburban high school. Harper Perennial: Harper Collins.

Cacciamani, S., Cesareni, D., Martini, F., Ferrini, T., \& Fujita, N. (2012). Influence of participation, facilitator styles, and metacognitive reflection on knowledge building in online university courses. Computers \& Education, 58(3), 874-884.

Chapman, E. (2003). Alternative approaches to assessing student engagement rates. Practical Assessment, 8(13), 1-7.

Chen, C.-H., \& Chiu, C.-H. (2016). Employing intergroup competition in multitouch design-based learning to foster student engagement, learning achievement, and creativity. Computers \& Education, 103, 99-113.

Chickering, A. W., \& Reisser, L. (1993). Education and identity, The Jossey-Bass Higher and Adult Education Series O. San Francisco: Jossey-Bass Inc., Publishers.

Christenson, S. L., Reschly, A. L., \& Wylie, C. (2012). Handbook of research on student engagement. Springer Science \& Business Media. Springer-Verlag New York.

Clark, R. E. (1994). Media will never influence learning. Educational Technology Research and Development, 42(2), 21-29.

Cline, J. L. (2013). Wired to bond: The influence of computer-mediated communication on relationships.

Coates, H. (2007). A model of online and general campus-based student engagement. Assessment \& Evaluation in Higher Education, 32(2), 121-141.

Connell, J. P., \& Wellborn, J. G. (1991). Competence, autonomy, and relatedness: A motivational analysis of self-system processes.

Corno, L. (1993). The best-laid plans: Modern conceptions of volition and educational research. Educational Researcher, 22(2), $14-22$

Creswell, J., \& Guetterman, T. (2019). Educational research: Planning, conducting, and evaluating quantitative and qualitative research. New York: US: Pearson Retrieved from https://www.pearson.com/us/higher-education.

Ding, L., Er, E., \& Orey, M. (2018). An exploratory study of student engagement in gamified online discussions. Computers \& Education, 120, 213-226.

Dunleavy, J., \& Milton, P. (2009). What did you do in school today. Exploring the concept of student engagement and its implications for teaching and learning in Canada. Toronto: Canadian Education Association, 14(1), 1-33.

Dweck, C. S., \& Master, A. (2008). Self-theories motivate self-regulated learning. In Motivation and self-regulated learning: Theory, research, and applications, (pp. 31-51).

Elliott, E. S., \& Dweck, C. S. (1988). Goals: An approach to motivation and achievement. Journal of Personality and Social Psychology, 54(1), 5 .

Ellis, R. (2009). The differential effects of three types of task planning on the fluency, complexity, and accuracy in L2 ora production. Applied Linguistics, amp042, 3-18. 
Finn, J. D., \& Voelkl, K. E. (1993). School characteristics related to student engagement. The Journal of Negro Education, 62(3), 249-268.

Fredricks, J. A. (2011). Engagement in school and out-of-school contexts: A multidimensional view of engagement. Theory Into Practice, 50(4), 327-335.

Fredricks, J. A., Blumenfeld, P. C., \& Paris, A. H. (2004). School engagement: Potential of the concept, state of the evidence. Review of Educational Research, 74(1), 59-109.

Fredricks, J. A., \& McColskey, W. (2012). The measurement of student engagement: A comparative analysis of various methods and student selfreport instruments. In Handbook of research on student engagement, (pp. 763-782). Boston: Springer.

Galikyan, I., \& Admiraal, W. (2019). Students' engagement in asynchronous online discussion: The relationship between cognitive presence, learner prominence, and academic performance. The Internet and Higher Education, 43, 100692.

Gholamshahi, A., \& Pazhakh, A. (2016). The effect of explicit teaching paralinguistic features on Ira-nian EFL learners'performance in English conversation in EFL context.

Glazer, E., Hannafin, M. J., \& Song, L. (2005). Promoting technology integration through collaborative apprenticeship. Educational Technology Research and Development, 53(4), 57-67.

González, M. D., Talavera-Velasco, B., \& Gutiérrez, S. U. (2020). The role of engagement and temporal perspective in the academic performance of postgraduate students. Physiology \& Behavior, 224, 113054.

Heidari-Shahreza, M. A., Moinzadeh, A., \& Barati, H. (2014). The effect of exposure frequency on incidental vocabulary acquisition. GEMA Online ${ }^{\oplus}$ Journal of Language Studies, 14(1).

Henrie, C. R., Halverson, L. R., \& Graham, C. R. (2015). Measuring student engagement in technology-mediated learning: A review. Computers \& Education, 90, 36-53.

Hilliges, O., Terrenghi, L., Boring, S., Kim, D., Richter, H., \& Butz, A. (2007). Designing for collaborative creative problem solving. In Paper presented at the proceedings of the 6th ACM SIGCHI conference on creativity \& cognition.

Hu, P. J.-H., \& Hui, W. (2012). Examining the role of learning engagement in technology-mediated learning and its effects on learning effectiveness and satisfaction. Decision Support Systems, 53(4), 782-792.

Hunsu, N. J. (2015). Issues in transitioning from the traditional blue-book to computer-based writing assessment. Computers and Composition, 35, 41-51.

Jiang, D., \& Zhang, L. J. (2020). Collaborating with 'familiar'strangers in mobile-assisted environments: The effect of socializing activities on learning EFL writing. Computers \& Education, 150, 103841

Khabiri, M., \& Bagher Khatibi, M. (2013). Mobile-assisted language learning: Practices among Iranian EFL learners. European Online Journal of Natural and Social Sciences, 2(2s), 176.

Kim, D., Lee, Y., Leite, W. L., \& Huggins-Manley, A. C. (2020). Exploring student and teacher usage patterns associated with student attrition in an open educational resource-supported online learning platform. Computers \& Education, 156, 103961.

Krause, K. L., \& Coates, H. (2008). Students' engagement in first-year university. Assessment \& Evaluation in Higher Education, 33(5), 493-505.

Kuh, G. D. (2008). Diagnosing why some students don't succeed. The Chronicle of Higher Education, 55(16), A72.

Kuh, G. D., Cruce, T. M., Shoup, R., Kinzie, J., \& Gonyea, R. M. (2008). Unmasking the effects of student engagement on firstyear college grades and persistence. The Journal of Higher Education, 79(5), 540-563.

Lamborn, S., Newmann, F., \& Wehlage, G. (1992). The significance and sources of student engagement. In Student engagement and achievement in American secondary schools, (pp. 11-39).

Lee, H.-G. (2012). ESL learners'motivation and task engagement in technology enhanced language learning contexts. Department of Language and Literacy Education, Washington State University.

Lin, G.-Y. (2020). Scripts and mastery goal orientation in face-to-face versus computer-mediated collaborative learning: Influence on performance, affective and motivational outcomes, and social ability. Computers \& Education, 143, 103691.

Liu, C.-C., Chen, W.-C., Lin, H.-M., \& Huang, Y.-Y. (2017). A remix-oriented approach to promoting student engagement in a long-term participatory learning program. Computers \& Education, 110, 1-15.

Liu, M., Liu, L., \& Liu, L. (2018). Group awareness increases student engagement in online collaborative writing. The Internet and Higher Education, 38, 1-8.

Lund, A. (2008). Wikis: A collective approach to language production. ReCALL, 20(1), 35-54.

Martin, A. J., \& Dowson, M. (2009). Interpersonal relationships, motivation, engagement, and achievement: Yields for theory, current issues, and educational practice. Review of Educational Research, 79(1), 327-365.

Martin, F., Wang, C., \& Sadaf, A. (2018). Student perception of helpfulness of facilitation strategies that enhance instructor presence, connectedness, engagement and learning in online courses. The Internet and Higher Education, 37, 52-65.

Mih, V., Mih, C., \& Dragoș, V. (2015). Achievement goals and behavioral and emotional engagement as precursors of academic adjusting. Procedia-Social and Behavioral Sciences, 209, 329-336.

Mohamadi, Z. (2017). Task engagement: A potential criterion for quality assessment of language learning tasks. Asian-Pacific Journal of Second and Foreign Lanquage Education, 2(1), 3.

Mohamadi, Z. (2018a). Comparative effect of online summative and formative assessment on EFL student writing ability. Studies in Educational Evaluation, 59, 29-40.

Mohamadi, Z. (2018b). Comparative effect of project-based learning and electronic project-based learning on the development and sustained development of English idiom knowledge. Journal of Computing in Higher Education, 30, 123.

Mohammadi, Z. (2017). Interactional complexity development, interactional demonstrators and interaction density in collaborative and e-collaborative writing modalities. Journal of Teaching Language Skills, 36(2), 75-102.

Moreira, P. A., \& Lee, V. E. (2020). School social organization influences adolescents' cognitive engagement with school: The role of school support for learning and of autonomy support. Learning and Individual Differences, 80, 101885.

Morett, L., Gibbs, R., \& MacWhinney, B. (2012). The role of gesture in second language learning: Communication, acquisition, \& retention. In Proceedings of the Annual Meeting of the Cognitive Science Society (Vol. 34, No. 34).

Murillo-Zamorano, L. R., Sánchez, J. Á. L., \& Godoy-Caballero, A. L. (2019). How the flipped classroom affects knowledge, skills, and engagement in higher education: Effects on students' satisfaction. Computers \& Education, 141, 103608. 
National Research Council (2003). Engaging schools: Fostering high school students' motivation to learn. National Academies Press.

Natriello, G. (1984). Problems in the evaluation of students and student disengagement from secondary schools. Journal of Research and Development in Education, 17(4), 14-24

Pascarella, E. T., \& Terenzini, P. T. (2005). How college affects students: A third decade of research, (vol. 2). Indianapolis: JosseyBass, An Imprint of Wiley.

Pereira, J. (2010). Handbook of Research on Personal Autonomy Technologies and Disability Informatics. publisher: IGI Global. https://doi.org/10.4018/978-1-60566-206-0.

Philp, J., \& Duchesne, S. (2016). Exploring engagement in tasks in the language classroom. Annual Review of Applied Linguistics, 36, 50-72.

Piccoli, G., Ahmad, R., \& Ives, B. (2001). Web-based virtual learning environments: A research framework and a preliminary assessment of effectiveness in basic IT skills training. MIS Quarterly, 25(4), 401-426.

Pietarinen, J., Soini, T., \& Pyhältö, K. (2014). Students' emotional and cognitive engagement as the determinants of well-being and achievement in school. International Journal of Educational Research, 67, 40-51.

Pineda-Báez, C., Manzuoli, C. H., \& Sánchez, A. V. (2019). Supporting student cognitive and agentic engagement: Students' voices. International Journal of Educational Research, 96, 81-90.

Pope, D. (2002). Doing school: How are we creating a generation of stressed-out, materialistic, and miseducated students? New Haven: Yale University Press.

Reeve, J., Cheon, S. H., \& Jang, H. (2020). How and why students make academic progress: Reconceptualizing the student engagement construct to increase its explanatory power. Contemporary Educational Psychology, 62, 101899.

Resta, P., \& Laferrière, T. (2007). Technology in support of collaborative learning. Educational Psychology Review, 19(1), 65-83.

Robayo-Tamayo, M., Blanco-Donoso, L. M., Román, F. J., Carmona-Cobo, I., Moreno-Jiménez, B., \& Garrosa, E. (2020). Academic engagement: A diary study on the mediating role of academic support. Learning and Individual Differences, 80, 101887.

Scardamalia, M., \& Bereiter, C. (2006). Knowledge building: Theory, pedagogy, and technology: na.

Snijders, I., Wijnia, L., Rikers, R. M., \& Loyens, S. M. (2020). Building bridges in higher education: Student-faculty relationship quality, student engagement, and student loyalty. International Journal of Educational Research, 100, 101538.

So, H.-J., Seah, L. H., \& Toh-Heng, H. L. (2010). Designing collaborative knowledge building environments accessible to all learners: Impacts and design challenges. Computers \& Education, 54(2), 479-490.

Tong, S., \& Walther, J. B. (2011). Relational maintenance and CMC. Computer-Mediated Communication in Personal Relationships, 53, 98-118.

van der Kleij, F. M. (2020). Evaluation of the 'feedback engagement enhancement tool'to examine and enhance students' engagement with feedback on their writing. Studies in Educational Evaluation, 66, 100907.

Walther, J. B., DeAndrea, D., Kim, J., \& Anthony, J. C. (2010). The influence of online comments on perceptions of antimarijuana public service announcements on YouTube. Human Communication Research, 36(4), 469-492.

Walther, J. B., Van Der Heide, B., Kim, S.Y., Westerman, D., \& Tong, S. T. (2008). The role of friends' appearance and behavior on evaluations of individuals on Facebook: Are we known by the company we keep? Human Communication Research, 34(1), 28-49.

Weiner, B. (1980). A cognitive (attribution)-emotion-action model of motivated behavior: An analysis of judgments of helpgiving. Journal of Personality and Social Psychology, 39(2), 186

Wenger, E. (1999). Communities of practice: Learning, meaning, and identity. Cambridge: Cambridge University Press.

Wenger, E. (2010). Communities of practice and social learning systems: The career of a concept. In Social learning systems and communities of practice, (pp. 179-198). Springer.

Williams, K. M., Stafford, R. E., Corliss, S. B., \& Reilly, E. D. (2018). Examining student characteristics, goals, and engagement in massive open online courses. Computers \& Education, 126, 433-442.

Willms, J. D. (2003). Student engagement at school. A sense of belonging and participation. Paris: Organisation for Economic Cooperation and Development.

Wolverton, C. C. (2018). Utilizing synchronous discussions to create an engaged classroom in online executive education. The International Journal of Management Education, 16(2), 239-244.

Xu, B., Chen, N.-S., \& Chen, G. (2020). Effects of teacher role on student engagement in WeChat-Based online discussion learning. Computers \& Education, 157, 103956.

Zhen, R., Li, L., Ding, Y., Hong, W., \& Liu, R.-D. (2020). How does mobile phone dependency impair academic engagement among Chinese left-behind children? Children and Youth Services Review, 116, 105169.

\section{Publisher's Note}

Springer Nature remains neutral with regard to jurisdictional claims in published maps and institutional affiliations. 